\title{
QUALITY INDICATORS APPLIED IN A NURSING CONTINUING EDUCATION PROGRAM OF A HIGH COMPLEXITY UNIVERSITY HOSPITAL FROM BRAZIL: I. ATTENDANCE INDICATORS
}

\author{
INDICADORES DE QUALIDADE APLICADOS A UM PROGRAMA DE EDUCAÇÃO \\ CONTINUADA DE UM HOSPITAL UNIVERSITÁRIO BRASILEIRO DE ALTA \\ COMPLEXIDADE: I. INDICADORES DE COMPARECIMENTO
}

\author{
Clesnan MENDES-RODRIGUES ${ }^{1,2,3, *}$; Eliana Borges Silva PEREIRA ${ }^{1,4}$; \\ Renata Lemos de SOUSA NETO ${ }^{1}$; Fabíola Alves GOMES ${ }^{1,2,4}$; Durval Veloso da SILVA ${ }^{1,5}$; \\ Arthur Velloso ANTUNES ${ }^{1,2}$; Rosângela de Oliveira FELICE ${ }^{1,4}$; Guilherme Silva \\ MENDONÇA $^{1,4}$; Paula Carolina Bejo WOLKERS ${ }^{1}$; Teresa Cristina Ferreira ALVES ${ }^{\mathbf{1}}$; \\ Rayany Cristina de SOUZA ${ }^{1,2}$; Dayane Aparecida Cândida FÉLIX ${ }^{1,2}$ \\ 1. Clinical Hospital of Uberlândia, Federal University of Uberlândia, Uberlândia, Brazil; 2. Nursing, Medicine Faculty, Federal \\ University of Uberlândia, Uberlândia, Brazil; 3. Institute of Biology, Statistics - Mathematics Faculty, Federal University of Uberlândia, \\ Uberlândia, Brazil; 4. Postgraduate Program in Health Sciences from Federal University of Uberlândia; 5. Postgraduate Program in \\ Environmental and Worker Health from Federal University of Uberlândia. \\ * Corresponding author: E-mail: clesnan@ hotmail.com
}

\begin{abstract}
Studies with nursing continuing education are common in the literature with a predominance of qualitative approaches. Quantitative assessments are punctual and focused on a single quality indicator, and few studies relate these indicators to the profile of nursing staff. The objective of the study was to describe the Training Cycles of the Clinical Hospital of Uberlândia as a strategy of a Nursing Continuing Education Program and evaluate the attendance indicators and their association with the nursing staff profile. The Training Cycles of the Clinical Hospital of Uberlândia are cyclic courses that are offered continually, in a mandatory participation regime, during work hours, outside of the hospital, focused on Nursing staff. The study was conducted in 2013/2014 and has a documentary character. It was held in a public high complexity university hospital in Brazil. The Relative Frequency Attendance was calculated in relation to the nursing professional category and shift. Attendance indicators were affected by professional category. Participation increased over time for the technical level (assistants and nursing technicians) and decreased for nurses. We found an attendance rate of $54.49 \%$ in nursing hospital staff. The attendance indicators were also different for the period/shift of the course (gradual decrease of attendance from morning to afternoon to night). We also observed a decrease in attendance indicators over time. Attendance indicators were effective in describing the results of the Continuing Education Program and allowed the service administrators to associate the indicator results to the nursing profile. These results served as a basis for adjustments in the continuing education program of the institution.
\end{abstract}

KEYWORDS: Training. Professional category. Public health policy. Work shift.

\section{INTRODUCTION}

We understand Continuing Education as the learning actions that individuals maintain after their professional formation, at any moment, including any professional practice, and obtained by various ways; although there are several definitions in the literature (ŞENYUVA, 2012; PERES; LEITE; GONÇALVES, 2010). As a subtype, we can classify professional continuing education as the Continuing Education directed to work actions. To follow the changes occurring in the work market, with the increase of technology and health publications, continuing education has been regarded as a strategy for the qualification of professionals as it updates their knowledge and improves their skills and abilities in clinical practice after formal education (JESUS et.al., 2011; NI et. al., 2014). Medicine or nursing, based on scientifically evidences, also corroborates the search for Continuing Education strategies. In literature, all professional education strategies devoted to professionals after formal education (continuing education, in service education, training and others) are treated as continuing education in a broad sense.

Continuing education in nursing has currently received the attention of professionals, health services and professional councils, and has been the subject of many theoretical studies of qualitative or quantitative approach (GRISCTI; JACONO, 2006). Many Nursing Councils have entered the continuing education programs as a requirement for the maintenance of records and performance of their professionals, such as in Australia (ROSS; BARR; STEVENS, 2013), China (NI et. al., 2014) and other countries. Nevertheless, 
in Brazil there is no specific policy of the Federal Council of Nursing, except the characterization of continuing education among its professionals (FIOCRUZ/COFEN, 2013). In most cases, continuing education is dependent on the interest of the professional and, in some cases, of the institutions. Often for professionals, this interest is focused on financial progression criteria of career plans, such as what occurs in the Brazilian federal public service (BRASIL, 2005), which offers financial benefits to those who participate and validate continuing education activities. The lack of financial return also seems to be one of the most important disincentives for continued education or training of nursing professionals (BREWER, ZAYAS, SIENKIEWICZ 2006; JOHNSON; COPNELL, 2002). Therefore, it is essential that the institutions offer adequate infrastructure and support for continuing education as a means of encouraging participation (CASEY; CLARK, 2009).

Although continuing education is present in the nursing context, there is little information regarding the aspects governing the participation and results obtained in continuing education programs in high complexity institutions, mainly in the Brazilian context. The evaluation of the results of the continuing education programs can lead to better planning of training actions and indirectly improve the nursing care provided to patients. Aspects such as professional category are rarely related to the results of Continuing Education Programs. We can cite as evaluated factors: the decrease in learning fixation with time in the absence of continuous refresher courses (GUARDINI et. al., 2008), increased attendance rates in mandatory participation schemes (SOUZA NETO; MENDES-RODRIGUES, 2017) and decrease in attendance rates over time in long-term courses with differential attendance between nursing professional categories (MENDONÇA et. al., 2016). In Brazil and in the literature, there are few quantitative studies on the results of continuing education programs, mainly using quality indicators to measure the programs.

There is a record of poor adherence of nursing professionals to continuing education if the course regime is voluntary (SOUZA NETO; MENDES-RODRIGUES, 2017). There is also the difficulty that teams are not designed to release individuals to attend these courses during work hours. With these two issues in mind, the Clinical Hospital of Uberlândia established in 2013 a Continuing Education Program. Within this program, the Training Cycle of the Clinical Hospital of Uberlândia (TCCHU) was proposed, which is a monthly mandatory course, during work hours and outside of the hospital structure.

The objective of this study was to describe and evaluate the attendance indicator as a quality indicator to evaluate the efficiency of the Training Cycle of the Clinical Hospital of Uberlândia, a continuing education strategy focused on nursing staff of a Brazilian university hospital. In addition, it also checked if the professional category and period of day (work shift) were able to interfere in these indicators.

\section{MATERIAL AND METHODS}

\section{Research Field}

The study was conducted at the Clinical Hospital of Uberlândia - CHU ("Hospital de Clínicas de Uberlandia - HCU") of the Federal University of Uberlândia - UFU ("Universidade Federal de Uberlândia - UFU"), state of Minas Gerais, Brazil. The hospital is classified as tertiary care (mainly devoted to care of high complexity patients), public and macro-regional, with a potential three million users distributed in the population of 86 surrounding cities. The $\mathrm{CHU}$ has 520 beds available in several clinical and surgical specialties and an emergency room, in addition to outpatient primary level units. Moreover, it is a university hospital that meets the Nursing, Medicine, and other health area undergraduate and postgraduate courses from UFU.

\section{Training Cycle of the CHU}

As a continuing education strategy of the Continuing Education Program of the CHU, the Nursing Direction proposed the TCCHU as a monthly activity, lasting three days, with three classes in the morning, afternoon and evening shifts, which allows offering the professional nine participation possibilities in each course. Within each TCCHU, two to four courses (lectures) are offered with varied times and themes, which are repeated in the nine periods. The lectures are mainly performed by the healthcare professionals from the CHU staff. Each TCCHU corresponds to six hours of training divided among the courses offered in each cycle. There is no separation of any nursing professional category for participation in the TCCHU, and the attendance is open to any other professional from UFU or healthcare professional from Uberlândia. The professional from the Nursing CHU staff is scheduled to participate during their work time (in a compulsory character) in one of the nine classes, and the course takes place outside of the physical dependencies of the Clinical Hospital 
of Uberlândia, but in the same campus where the $\mathrm{CHU}$ is located. The worker can change the day of participation, regardless of schedule, facilitating their participation. In all cases the course is performed during working hours. The themes of the courses are varied and based on discussions of the needs of nursing professionals, lawful requirements (course required by the legislation from healthcare services), demands of the CHU (courses focused on actual problems or daily difficulties of the hospital) or indications of the professionals themselves. The course has a mandatory regime of participation, but the nursing chief from each hospital unit can change this regime in any cycle or time.
The original proposition was for the cycle to be monthly, but for many reasons it was offered only in some months due to strikes, replacement by other events, etc. The first 12 TCCHU were evaluated by this study, being the $1^{\text {st }}$ to the $4^{\text {th }}$ TCCHU performed in 2013 and the $5^{\text {th }}$ to the $12^{\text {th }}$ in 2014. The cycles were ordered from 1 to 12 depending on the temporal order in which they occurred. For all tests, data from two courses were excluded, as they were not offered in the nine classes and for all participants because of the occurrence of a strike and health problems of one of the speakers. There were 33 courses offered by the TCCHU with varied themes (Table 1).

Table 1. Course themes offered in the Training Cycles of the Clinical Hospital of Uberlândia as part of a Continuing Education Program in 2013 and 2014 of the Clinical Hospital of Uberlândia, a tertiary and university hospital from Brazil.

\begin{tabular}{|c|c|c|}
\hline Year & Order & Course Theme \\
\hline \multirow[t]{2}{*}{2013} & 1 & Transfusion safety \\
\hline & & Precaution and isolation system \\
\hline \multirow[t]{2}{*}{2013} & 2 & Patient transport safety \\
\hline & & Intra-hospital Commission of Organ and Tissue Donation for Transplantation \\
\hline \multirow[t]{2}{*}{2013} & 3 & Enteral and parenteral nutrition therapy \\
\hline & & Basic interpretation of electrocardiograms \\
\hline \multirow[t]{3}{*}{2013} & 4 & Adult cardiopulmonary resuscitation \\
\hline & & Neonatal cardiopulmonary resuscitation \\
\hline & & Nursing care to the client in cardiopulmonary arrest \\
\hline \multirow[t]{4}{*}{2014} & 5 & Peripherally inserted central catheter care \\
\hline & & General Standard Operating Procedure - 1 \\
\hline & & Healthcare Humanization \\
\hline & & Nursing professional ethic legislation \\
\hline \multirow[t]{3}{*}{2014} & 6 & Nursing care in mental heath \\
\hline & & Nursing registers \\
\hline & & General Standard Operating Procedure - 2 \\
\hline \multirow[t]{2}{*}{2014} & 7 & Nursing care to burn victims: Care Stratification \\
\hline & & General Standard Operating Procedure - 3 \\
\hline \multirow[t]{3}{*}{2014} & 8 & Breastfeeding \\
\hline & & Obstetric emergencies \\
\hline & & Humanized childbirth \\
\hline \multirow[t]{3}{*}{2014} & 9 & Training in organ and tissue donation for transplantation \\
\hline & & Nursing care for patients in mechanical ventilation \\
\hline & & New transfusion form implementation \\
\hline \multirow[t]{3}{*}{2014} & 10 & Hospital residue management policies \\
\hline & & Process management and quality tools \\
\hline & & Nursing care to cancer patients \\
\hline \multirow[t]{3}{*}{2014} & 11 & Flow and materials processing in sterilization center \\
\hline & & Prevention and control of healthcare-related infections \\
\hline & & Propaedeutics: preparing patients for exams \\
\hline \multirow[t]{3}{*}{2014} & 12 & Work periodic inspections and monitoring of biological accidents \\
\hline & & Hypodermoclysis \\
\hline & & Nursing care to renal and kidney transplanted patients \\
\hline
\end{tabular}




\section{Population Study}

The study population was the professionals of the CHU Nursing Direction. All other professionals who were not part of the CHU staff were included in only some analyses as a category called "Others", being excluded from further analyses, regardless of their area of operation in the hospital. The CHU has a Nursing Direction, which manages about 1,152 nursing professionals, distributed in about 38 administrative units (ANTUNES et. al., 2013). The number of professionals in the institution varies, but this was not accompanied throughout the study. This oscillation is small because of the staff maintenance policy of the federal government. Therefore this did not hinder the study. These professionals are divided in three professional nursing categories: nursing assistant, nursing technician and nurse, according to Law 7,498 from 1986 (BRASIL, 1986). Nursing assistants (nursing auxiliaries or aides) are responsible for basic care to patients, have a basic level of education completed in nine years of formal education (equivalent to elementary school), as well as a compulsory training course of one year. The nursing technicians are responsible for the patient's intermediate care, have an average level of education completed in 12 years of formal education (elementary plus secondary education), as well as a compulsory training course of two to three years. Nurses are responsible for health services management, some private and high complexity care, and have an average level of education of 12 years of education (elementary plus secondary education), and an undergraduate level of four-five years (University). Further details about the evolution of professional nursing categories in Brazil can be found at Neves and Mauro (NEVES: MAURO, 2000). The detailed professional practice of nursing in Brazil is described in Law 7,498 from 1986 (BRASIL 1986). In 2003, the Nursing Assistant course ceased to be offered and professionals had to be trained to meet the needs of the Nursing Technician category (COFEN, 2003). From that date, it was also no longer possible to register in the nursing assistant category, although professionals who had been previously registered as Nursing Assistants remain in that category. In this study, we considered the professional category under which the professional was contracted in the institution, regardless of having any other formation.

\section{Ethical Implications}

The study was not submitted to the Ethics Committee of the Federal University of Uberlândia, as it was and is a study of management and administrative nature. Data were collected and analyzed to be part of the evaluation of management activities and control of the CHU Nursing Department. The data were not collected in advance to be used as a research project. The data collected from participants are public and are part of necessary information for the registration, validation and control of nursing training activities for vigilance from federal and internal control agencies. All information herein is public and routinely collected by the CHU, and the study was approved internally by hospital staff. There is no way to recognize any individual who participated in any part of the work. All data, analyses and interpretation were internally presented and approved by the Hospital Directors with the intention to promote continuing education policies of the institution.

\section{Attendance indicators}

The number of participants was counted in each class of the offered courses. The classes were separated by shift or work time and classified as morning, afternoon or evening. The number of participants from the nine classes for each course were summed to compound the total number of professionals per course. As the number of professionals oscillated between courses in each cycle the total number of professionals per TCCHU was not calculated. In this last case, the total number of professionals per TCCHU was evaluated by the total number of professionals per course per cycle.

To understand the distribution of the professionals, we calculated the Relative Frequency Attendance (RFA), as an attendance indicator. This indicator was used since the number of professionals oscillated between cycles and it represents the relative frequency of attendance in each category evaluated from each cycle independently of the number of professionals that participated in a course or who are attributed to a certain classification. The RFA was calculated by NP/TNP*100, where NP represents the number of professionals in the category evaluated; TNP represents the total number of professionals (sum of number of professionals in all categories evaluated).

We calculated the RFA of each class from each course and of each cycle. We also calculated the sum of the RFA by shift (sum of the three classes of each shift). Since we intend to understand the use of different shifts or classes by professionals, we considered all participants of the TCCHU, independent of whether or not they belonged to Clinical Hospital of Uberlândia Nursing staff. 
Based on the presence registers, we calculated the number of nurses, nursing technicians and nursing assistants from the CHU staff in each TCCHU. The sum of the three areas was also considered the total number of participating nursing professionals in each cycle. The number of participating professionals who are not part of the CHU Nursing staff was also calculated and classified as other professionals. Since the total number of participants per cycle decreased over time, we calculated the RFA by professional nursing categories as follows: NP was considered the number of professionals in each nursing category, and TNP the sum of all professionals in each category in each cycle. While the RFA was calculated for the category other professionals, the TNP was considered the total number of professionals at each cycle, regardless of being CHU staff or not.

\section{Statistical Analysis}

In the analysis where we considered the temporal order of cycles, this order was obtained by the sequence of cycles in the two years evaluated, regardless of the interval between one cycle and the next, being ordered as 1 to 4 for the $1^{\text {st }}$ to $4^{\text {th }}$ TCCHU of 2013 and as 5 to 12 for the $1^{\text {st }}$ to $8^{\text {th }}$ TCCHU of 2014. This was proposed with the intention of verifying the change in the quality indicators in relation to the sequential offering of Training Cycles, not in relation to the real time between each training cycle.

To compare the mean RFA between the nursing professional categories and the mean RFA per class between shifts, we used the Generalized Linear Model (GLM), and for post-hoc comparisons the Least Significance Difference test (LSD) when necessary; adopting Gaussian distribution of data. The range and the coefficient of variation of RFA per class was calculated for each shift to explore the variability in this indicator.

The data of RFA for each professional category, shift, number of professionals per cycle and nursing staff number per course were fitted to linear regression models. The fitting of the model was tested with ANOVA. The intercept and slope from the model were tested with Student's $t$ test. As an independent variable, we adopted the temporal order of cycles (1 to 12) and as the dependent variable, the RFA of each professional category, shift, and number of professionals per cycle and nursing staff number per course.

All analyses were performed using the SPSS 20.0 package. A 5\% significance level was adopted for all analyses.

\section{RESULTS}

During the years 2013 and 2014, 12 Training Cycles were offered that totaled 33 courses of diverse themes (Table 1). Initially $20 \mathrm{TCCHU}$ were programmed, but only $60 \%$ of that number was offered. Of the 35 initially offered courses, only $33(94.28 \%)$ were actually offered in nine classes. Two courses were excluded from the analyses because they were not offered in all nine classes.

The mean of total number of professionals per cycle was 619.18 (minimum $=486$, maximum 831 , median $602, \mathrm{n}=33$ ). The mean of total number of nursing $\mathrm{CHU}$ professionals per cycle was 627.75 (minimum $=492$, maximum 693, median $644, \mathrm{n}=$ 12). Adopting 1152 nursing professionals in the CHU we found an attendance rate of $54.49 \%$ in the TCCHH, oscillating from 42.71 to $60.16 \%$.

The data showed that the mean relative frequency of attendance by class differed between all shifts $\left(\chi^{2}=814.16, P<0.001\right.$, Fig $\left.1 \mathrm{~A}\right)$. The morning shift showed the highest value (mean $14.51 \%$ per class) followed by the afternoon (mean $12.40 \%$ per class) and evening (mean $8.6 \%$ per class). The greater range of RFA per class was in the morning followed by the afternoon, although the variability was greater in the evening shift $(\mathrm{CV}=$ $29.12 \%$ ), showing a preference of the workers for the first two periods (Figure 1B). The students or professionals from hospital areas other than nursing preferred to participate in the morning shift.

When the temporal order of the cycles was assessed to verify if it affects the RFA per shift, we found that in the morning shift there was an adjustment to the linear model and a decrease in the RFA per shift with the increase of the order of cycles (Fig 1C, $F_{1,31}=16.402, P<0.001, R^{2}=$ $0.346 ; t$ for $\beta_{0}=47.09 P<0.001, t$ for $\beta_{1}=-4.05, P<$ 0.001 ); while there was no linear adjustment for the afternoon shift (Fig 1D, $F_{1,31}=0.007, P=0.936, R^{2}$ $=0.000)$ and in the evening there was an increase in the RFA per shift with the increase in the order of the cycles (Fig 1E, $F_{1,31}=10.008, P=0.003, R^{2}=$ 0.244; $t$ for $\beta_{0}=18.90 P<0.001, t$ for $\beta_{1}=3.16, P=$ $0.003)$. Furthermore, the total number of professionals per course also had a sharp decrease due to the increase in the temporal order of the cycles, with a reduction of 16.366 professionals per cycle (Fig $1 \mathrm{~F}, F_{1,31}=29.707, P<0.001, R^{2}=0.489$; $t$ for $\beta_{0}=31$. 99, $P<0.001, t$ for $\beta_{1}=-5.45, P<$ $0.001)$. 

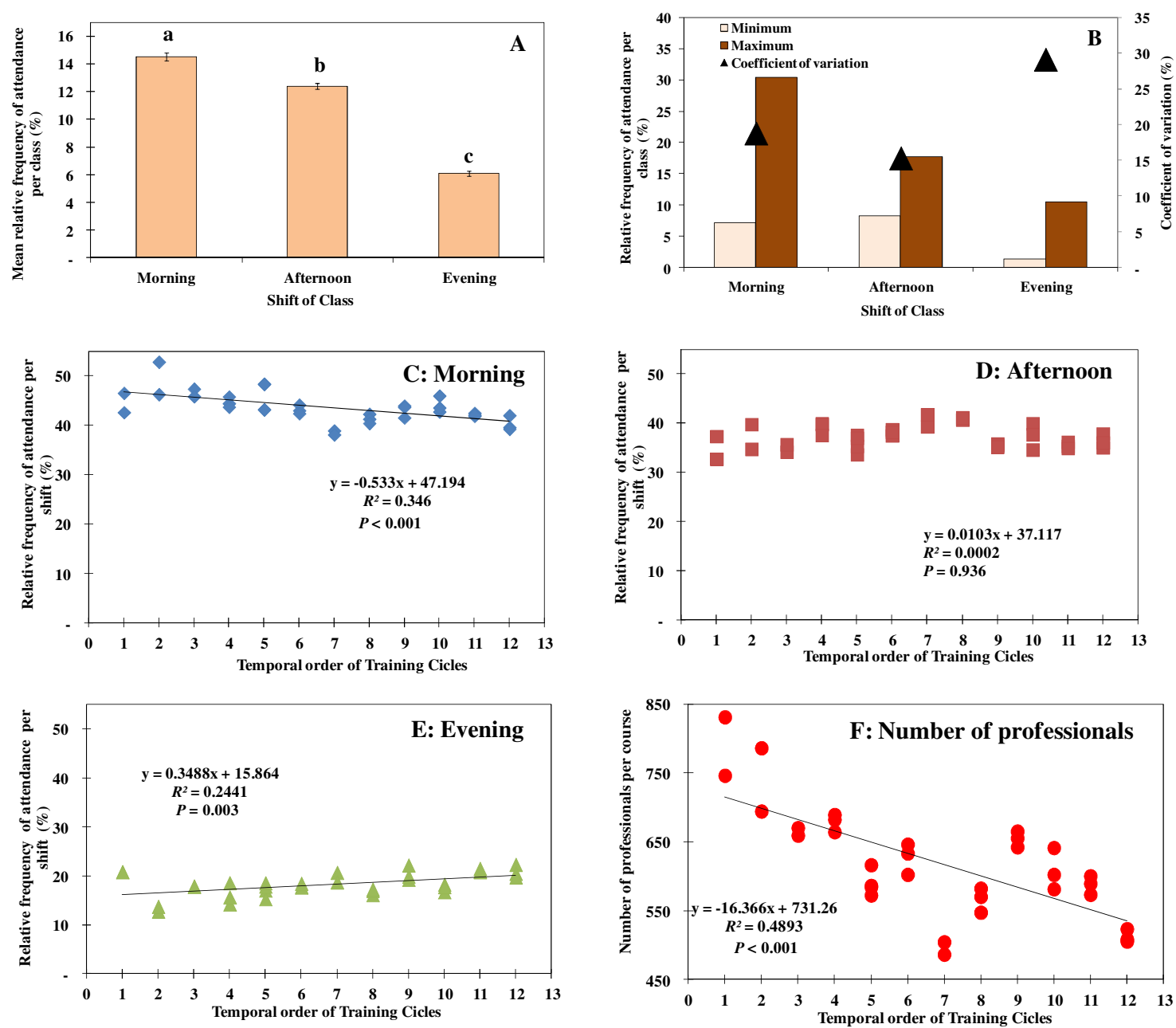

Figure 1. Relation between relative frequency of attendance and other indicators with the temporal order of the Training Cycles of the Clinical Hospital of Uberlândia, a continuing education strategy of a university hospital from Brazil. (Temporal order: 1 to 4: 2013 and 5 to 12: 2014).

(A) Mean relative frequency of attendance per class per shift; (B) Minimum, Maximum and Coefficient of Variation of relative frequency of attendance per class per shift; (C) (C-D) Relation between the relative frequency of attendance with the temporal order of Training Cycles per shift: (C) Morning. (D) Afternoon. (E) Evening. (F) Relation between the total number of professionals per course with the temporal order of Training Cycles.

There was no fitting to the linear regression model of the RFA of nursing assistants per cycle (Fig $2 \mathrm{~A}, F_{1,10}=0.524, P=0.486, R^{2}=0.050$ ), and nursing technicians per cycle (Fig $2 \mathrm{~B}, F_{1,10}=4.162$, $P=0.069, R^{2}=0.294$ ), while the RFA of nurses per cycle sh

owed a linear adjustment demonstrating that the RFA decreased with the temporal order of cycles (Fig 2C, $F_{1,10}=22.307, P<0.001, R^{2}=0.690 ; t$ for $\beta_{0}=20.117, P<0.001, t$ for $\beta_{1}=-4.723, P=0.001$ ). When the trend was evaluated for other professionals, the frequency also did not adjust for the linear model $\left(y=0.7267 x+1.4708, F_{1,10}=2.395\right.$, $\left.P=0.153, R^{2}=0.193\right)$. However, when the RFA of nursing assistants and the RFA of technicians per cycle was summed, the data adjusted to the linear model $\left(y=82.792+0.549 x, \quad F_{1,31}=22.307, P=\right.$
$0.001, R^{2}=0.690 ; t$ for $\beta_{0}=96.81, P<0.001, t$ for $\beta_{1}=4.723, P<0.001$ Fig $\left.2 \mathrm{D}\right)$, showing that the RFA per cycle increased with the increase in the temporal order of the cycles.

The data correction for relative frequency was appropriate, since the total nursing professionals number per cycle (all three categories grouped) declined over the temporal order of cycles with a reduction of 15.58 professionals per cycle, with data adjusted to the linear model (Fig 1E, $F_{1,31}$ $=22.722, P=0.001, R^{2}=0.694 ; t$ for $\beta_{0}=28.667, P$ $<0.001, t$ for $\left.\beta_{1}=-4.767, P=0.001\right)$. In addition, the mean RFA per cycle of each category was different among all categories $\left(F_{2,33}=1133.85, P<\right.$ 0.001 ), with higher values for nursing technicians, followed by nursing assistants and nurses, respectively (Fig 2F). 

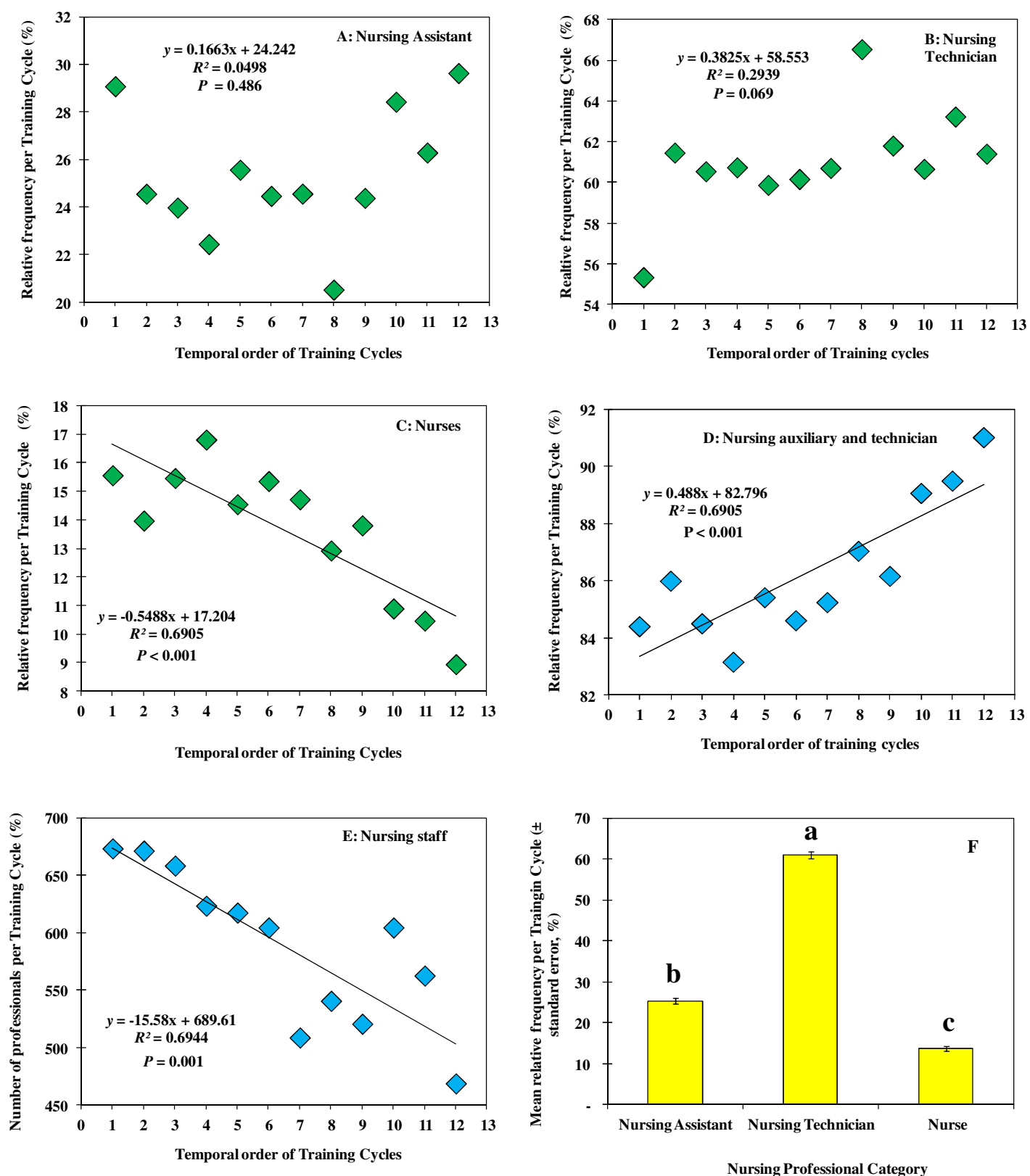

Figure 2. Relative frequency of attendance by nursing professional category in relation to the temporal order of Training Cycles of the Clinical Hospital of Uberlândia, a continuing education strategy of a university hospital from Brazil. (Temporal order: 1 to 4: 2013 and 5 to 12: 2014).

Relative frequency of attendance per cycle of: (A) Nursing Assistants, (B) Nursing Technicians, (C) Nurses, (D) Nursing Assistants and Technicians. (E) Absolute frequency for Nursing staff. (F) Mean relative frequency per Training Cycle per Nursing professional category, where mean values followed by different letters are statistically different $(P<0.05)$.

\section{DISCUSSION}

\section{Training Cycle impacts in healthcare organization}

Training and continuing education during working hours, in a voluntary participation regime and in the hospital facilities, was commonly offered by the Clinical Hospital of Uberlândia and many other health services. The low attendance at these training courses highlights difficulties of the managers to release their professionals who are in direct patient care. Often the professionals interrupt their participation during the training and return to the direct patient assistance. In addition, many nurses that participated in these courses ended up not sharing their training in their units due to the high flow of patient care and administrative activities in inpatient units. Offering a course 
during working hours, but with a mandatory regime and outside of the work environment (outside the hospital), as in the TCCHU, facilitated all the training dynamics in the hospital evaluated here with greater staff adhesion. A comparative study between voluntary and mandatory participation in a patient safety course in the same institution showed that in the voluntary participation regime only about $9 \%$ of professionals were trained compared to $72 \%$ in the mandatory regimes (SOUZA NETO; MENDES-RODRIGUES, 2017), while another study shows low attendance (39.66\%) when voluntary participation was adopted in some units of the same hospital (PEREIRA et. al., 2017a). Other strategies, as long-term courses in regimes of voluntary participation, also show low adherence and a decrease of attendance over time (MENDONÇA et. al., 2016). Apparently the mandatory regime was primordial to improve the attendance indicator in the institution studied. Indicators form other scenarios in the institution are absent, and that impairs the comparison of the data.

The offering of courses within the facilities of the institutions seems to be essential for the development of the continuing education program. As evaluated here, the course was outside of the hospital, but near the hospital in the university facilities. The participation in courses within the workplace is a major source of improvement used by professionals (NI et al., 2014). This information highlights the need for a new perception by managers and health services that should serve as a source and facilitators of participation of teams in continuing education programs (GOULD; DREY; BERRIDGE, 2007), allowing the deployment of knowledge and expertise in health services. The TCCHU is managed by a specific continuing education team, which makes the offering of training easier.

Although the attendance at mandatory courses does not necessarily translate in a gain of knowledge, one must evoke the perception of continuing education as part of the work (SENGE, 1990), since the participation in continuing education programs has been related to the increase of motivation and competence at work (PUETZ, 1980). However, some authors claim that the Continuing Education Programs have failed to encourage professionals to be their own learning managers (GRISCTI; JACONO, 2006). The TCCHU has provided an increase in knowledge in its participants (PEREIRA et. al., 2017b). The low attendance in training sessions (attendance rate $=$ $39.66 \%$ ) about hand hygiene impaired the implementation and the knowledge increase in a multimodal strategy that aimed to reduce healthcare associated infections (PEREIRA, et. al., 2017a), in the same institution studied here. These events reinforce the need for discussion of the participation regimes in Continuing Education Programs.

\section{Attendance Indicators}

Studies with application of attendance indicators or other quality indicators of Continuing Education Programs in Brazilian institutions are still missing, which prevents the comparison of our data to other studies. Labor activities, time constraints, and cost of courses have been widely reported as factors that hinder adherence to Continuing Education in Nursing services (BREWER; NAUENBERG, 2003; NI al., 2014; HAMZEHGARDESHI; SHAHHOSSEINI, 2014; CHONG et. al., 2011). In addition, some situations make the professionals dissatisfied and unmotivated to work and to participate in continuing education programs. These situations are related to different forms of employment, which provide benefits to some of the professionals (JESUS et. al., 2011), such as opportunity of career development for federal servers in the institution under study. Federal employees don't enjoy the same benefits.

The indicators show that the course could be reduced to only two days (six classes) if they were equally frequented, presenting an RFA = 11.11 , since many classes are underutilized. The night shift is the most underutilized. The strong differences in attendance indicators in function of shift could demonstrate the preference of the nursing professionals for day training activities in detriment of the night. The professionals that work at night had the option of training during the day. Consequently they could have the night off or work a 12-hour extra shift increasing their economical returns. Normally night nursing professionals experience healthcare problems related to sleep deprivation that could interfere with healthcare assistance (GAMBLE et. al., 2011), or in our case in the choice of the shift to participate in the training. In Training Cycles, the professional could voluntarily change the time of participation without any loss, which improved the attendance rate.

The time spent with participation in courses was identified as an obstacle to the acquisition of postgraduate or training certification along with wage losses related to the reduction of working hours caused by participation in training outside of working hours (JOHNSON; COPNELL, 2002), which discourages participation in these activities. 
Often the lack of access to formal or continuing education has decreased the permanence of professionals in the profession associated with low valuation of these initiatives by the healthcare labor market (GRANZOTTO et. al., 2008). We do not know other studies that assessed training indicators by comparing training offered in and out of working hours.

We did not find a clear and definitive explanation to the decrease in RFA of nurses over time. The lack of professionals to meet the demands of assistance activities has limited continuing education (GOULD; DREY; BERRIDGE, 2007). The nurses might need to take on more patient assistance activities so members of their team may participate in training activities, as evidenced by the lower mean hours of training of these professionals. Moreover, the nurses might mistakenly perceive the Training Cycles as an activity directed to nursing assistants and technicians, and end up minimizing the impact of the Training Cycle on the Nurses category. The factors that trigger this low participation of Nurses, especially over the time, are not known but deserve the attention of managers. The differential use of professional nursing categories in Brazil seems a constant in the assessments of knowledge when these categories are not segregated (GRANZOTTO et al., 2008; CASTELLÕES; SILVA, 2007). In addition, other training indicators also show differences between professional nursing categories in the same institution, such as approval, fail and drop out rates, which also differ among the categories in long-term courses (MENDONÇA et. al., 2016).

The presence of different professional categories in Nursing is a constant in Brazil since the formation of Nursing in the country (NEVES; MAURO, 2016), but recently the increase of access to education and the extinction of the nursing assistant category have reduced the differences between the categories. About $31.4 \%$ of Brazilian nurses attended nursing technician courses before graduation and $80 \%$ have some level of postgraduation, and $34.3 \%$ of Technicians or Assistants have complete or incomplete higher education (FIOCRUZ/COFEN, 2016). Continuing Education Programs need to evaluate the necessities of each nursing professional mainly in a scenario where their formal education level is higher than demanded by their work contract.

Alternatives for the low attendance indicators in continuing education courses have been tested. For example, Canchihuaman et al. (2011) demonstrated the Internet-based Continuing
Education improves the participation rates and knowledge in the course with good satisfaction indicators. Another example is the comparative study of classroom and online distance modes of official vocational education and training evaluated by Lopes; Gaza and Ramirez (2014), which provides evidence that a broad offering of vocational education and training opportunities will facilitate access to such learning for students who require it. Besides these alternatives, it is not our intention to compare the data here obtained to these strategies, only to show that new alternatives have been proposed in order to improve the learning and attendance rates, and in this context the use of attendance indicators could offer opportunities of better understand this scenarios. In our case, the alternative of mandatory participation training outside hospital dependencies and a cyclic offering was effective to incentivize attendance.

The use of indicators of continuing education should be part of the evaluation of health services, primarily because of the positive results of continuing education on the quality of health services provided and patient health indicators (HASHJIN et. al., 2014). Besides, currently their use is mostly directed towards external accountability purposes, but strategies are needed to support internal quality improvement processes at hospital level (JERICÓ; CASTILHO, 2004), and in our case in future planning of Continuing Education Programs.

\section{CONCLUSIONS}

The Clinical Hospital of Uberlândia is offering continuing education courses during work hours, in the institution facilities outside of the hospital and under mandatory participation regime.

The use of the attendance indicators proposed here (mainly the RFA) help to understand the participation of the nursing staff. This is important to optimize the resources involved in offering said courses. In the institution evaluated here, the attendance indicators formed the basis and source of information for adjustments in the continuing education program of the institution.

The main findings are the differentiated attendance of the nursing professional categories, mainly low for nurses, low participation in evening shift and the decrease of participation over time.

\section{ACKNOWLEDGEMENTS}

The authors are grateful to all those who directly or indirectly provided the realization of the 
Training Cycles of HCU in 2013 and 2014, and all participants of the cycles, especially the nursing staff of the Hospital de Clínicas de Uberlândia.
Thanks to Igor de Oliveira Felice and Roger Hutchings for the English version.

RESUMO: Estudos com educação continuada em enfermagem são comuns na literatura, embora com predominância de abordagem qualitativa. Avaliações quantitativas são pontuais e concentradas em um único indicador de qualidade, e em raros casos relacionam estes indicadores com o perfil da enfermagem. O objetivo deste estudo foi descrever o Ciclo de Capacitação do Hospital de Clínicas de Uberlândia como uma estratégia de um Programa de Educação Continuada em Enfermagem e avaliar os indicadores de comparecimento desse programa e sua associação com o perfil dos profissionais de enfermagem. O Ciclo de Capacitação do Hospital de Clínicas de Uberlândia é um curso cíclico que é oferecido continuamente, em um regime de participação obrigatória, durante as horas de trabalho, fora do hospital, e dedicado à equipe de enfermagem. O estudo foi realizado em 2013/2014, tem caráter documental, foi realizado num hospital público, de alta complexidade e universitário no Brasil. Foi calculado a Frequência Relativa de Comparecimento em função da categoria profissional e do plantão. Observamos uma taxa de comparecimento de 54.49\% para os profissionais de enfermagem do hospital. Os indicadores de comparecimento foram afetados pela categoria profissional (aumento da participação ao longo do tempo para os profissionais de nível técnico (auxiliares e técnicos de enfermagem) e diminuição da participação dos enfermeiros. Houve diferenças entre os turnos de oferecimento do curso (diminuição gradativa da participação da manhã para a tarde e desta para a noite). Observou-se também a redução nos indicadores de comparecimento ao longo dos cursos em função do tempo de oferecimento. Os indicadores de comparecimento propostos foram eficazes em descrever os resultados e o comportamento do programa de educação continuada e permitiram associar seus resultados ao perfil dos profissionais de enfermagem e serviram de embasamento para ajustes no programa de educação permanente da instituição.

PALAVRAS-CHAVE: Treinamento. Categoria profissional. Políticas publicas de saúde. Plantão de trabalho.

\section{REFERENCES}

ANTUNES, A. V.; MENDES-RODRIGUES, C.; GOMES, F. A.; REZENDE, G. J.; BRAGA, I. A.; TEIXEIRA, L. M. R.; MONTEIRO, A. B. C. Dimensionamento de Pessoal de Enfermagem (Technical Report). Uberlândia: Universidade Federal de Uberlândia - Hospital de Clínicas de Uberlândia, 2013. 93 p.

BRASIL. Presidência da Republica, Casa Civil. Lei 7.498, de 25 de junho de 1986. Dispõe sobre a Regulamentação do Exercício da Enfermagem e dá outras providências. Brasília: Ministério da Saúde, 1986. Available: <http://www.planalto.gov.br/ccivil_03/leis/l7498.htm>. Accessed [16 Aug 2017].

BRASIL. Presidência da Republica, Casa Civil. Lei no 11.091, de 12 de janeiro de 2005. Dispõe sobre a estruturação do Plano de Carreira dos Cargos Técnico-Administrativos em Educação, no âmbito das Instituições Federais de Ensino vinculadas ao Ministério da Educação, e dá outras providências. Available: $<$ http://www.planalto.gov.br/ccivil_03/_ato2004-2006/2005/lei/111091.htm>. Accessed [16 Aug 2017].

BREWER, C. S.; NAUENBERG, E. Future intentions of registered nurses employed in the western New York labor market: Relationships among demographic, economic, and attitudinal factors. Applied Nursing Research, Philadelphia, v. 16, n. 3, p. 144-155, 2003. https://doi.org/10.1016/S0897-1897(03)00046-6

BREWER, C. S.; ZAYAS, L. E.; SIENKIEWICZ, M. J. Nursing recruitment and retention in New York State: A qualitative workforce needs assessment. Policy, Politics, \& Nursing Practice, Thousand Oaks, v. 7, n. 1, p. 54-63, 2006. https://doi.org/10.1177/1527154406286335

CANCHIHUAMAN, F. A.; GARCIA, P. J.; GLOYD, S. S.; HOLMES, K. K.. An interactive internet-based continuing education course on sexually transmitted diseases for physicians and midwives in Peru. PLOS ONE, San Francisco, v. 6, n. 5, p. e19318, 2011. https://doi.org/10.1371/journal.pone.0019318

CASEY, D.; CLARK, L. Professional development for registered nurses. Nursing Standard, London, v. 24, n. 15-17, p. 35-38, 2009. https://doi.org/10.7748/ns2009.12.24.15.35.c7438 
CASTELLÕES, T. M. F. W.; SILVA, L. D. Resultados da capacitação para a prevenção da extubação acidental associada aos cuidados de Enfermagem. Revista Mineira Enfermagem, Belo Horizonte, v. 11, n. 2, p. 168175, 2007.

COFEN. Resolução COFEN-276/2003. Regula a Concessão de Inscrição Provisória ao Auxiliar de Enfermagem Available: < http://www.cofen.gov.br/resoluo-cofen-2762003-revogada-pela-resoluo-cofen3142007_4312.html>. Accessed [16 Aug 2017].

CHONG, M. C.; SELLICK, K.; FRANCIS, K.; ABDULLAH, K. L. What influences Malaysian nurses to participate in continuing professional education activities? Asian Nursing Research, Singapore, v. 5, n. 1, p. 38-47, 2011. https://doi.org/10.1016/S1976-1317(11)60012-1

FIOCRUZ/COFEN - Fundação Osvaldo Cruz/Conselho Federal de Enfermagem. Perfil da Enfermagem Rio Janeiro [internet]. Pesquisa Perfil da Enfermagem no Brasil 2013. [cited 2016 July 13] Available from: $<$ http://rj.corens.portalcofen.gov.br/veja-aqui-os-dados-fluminenses-da-pesquisa-perfil-da-enfermagem-nobrasil_2455.html>

GAMBLE, K. L.; MOTSINGER-REIF, A. A.; HIDA, A.; BORSETTI, H. M.; SERVICK, S. V.; CIARLEGLIO, C. M.; ROBBINS, S.; HICKS, J.; CARVER, K.; HAMILTON, K.; WELLS, N.; SUMMAR, M. L.; MCMAHON, D. G.; JOHNSON, C. H. Shift work in nurses: Contribution of phenotypes and genotypes to adaptation. PLOS ONE, San Francisco, v. 6, n. 4, p. e18395, 2011.

https://doi.org/10.1371/journal.pone.0018395

GOULD, D.; DREY, N.; BERRIDGE, E. Nurses' experiences of continuing professional Development. Nurse Education Today, Oxford, v. 27, p. 602-609, 2007. https://doi.org/10.1016/j.nedt.2006.08.021

GRANZOTTO, J. A.; SCHNEID, S.; VECCHI, A. A.; AZEVEDO, N. A.; PADILHA, M. A.; MEDEIROS, A. C.; BEBBER, F. E.; PILOWNIC, C.; LUDTKE, I. N. Basic life support training in a university hospital. Revista da AMRIGS, Porto Alegre, v. 52, n. 1, p. 24-28, 2008.

GRISCTI, O.; JACONO, J. Effectiveness of continuing education programmes in nursing: literature review. Journal of Advanced Nursing, Weinheim, v. 55, n. 4, p. 449-56, 2006. https://doi.org/10.1111/j.13652648.2006.03940.x

GUARDINI, I.; TALAMINI, R.; LIRUTTI, M.; PALESE, A. The effectiveness of continuing education in postoperative pain management: results from a follow-up study. Journal of Continuing Education Nursing, Thorofare, v. 39, n. 6, p. 281-288, 2008. https://doi.org/10.3928/00220124-20080601-08

HAMZEHGARDESHI, Z.; SHAHHOSSEINI, Z. A cross-sectional study of facilitators and barriers of Iranian nurses' participation in continuing education programs. Global Journal of Health Science, Toronto, v. 6, n. 2, 2014. https://doi.org/10.5539/gjhs.v6n2p183.

HASHJIN, A. A.; RAVAGHI, H.; KRINGOS, D. S.; OGBU, U. C.; FISCHER, C.; AZAMI, S. R.; KLAZINGA, N. S. Using quality measures for quality improvement: The perspective of hospital staff. PLOS ONE, San Francisco, v. 9, n. 1, p. e86014, 2014. https://doi.org/10.1371/journal.pone.0086014k

JERICÓ, M. C.; CASTILHO, V. Análise de alguns indicadores relacionados aos recursos humanos de uma organização hospitalar. Nursing, São Paulo, v. 7, n. 74, p. 23-27, 2004.

JESUS, M. C. P.; FIGUEIREDO, M. A. G.; SANTOS, S. M. R.; AMARAL, A. M. M.; ROCHA, L. O.;

THIOLLENT, M. J. M. Permanent education in nursing in a university hospital. Revista da Escola de Enfermagem da USP, São Paulo, v. 45, n. 5, p. 1229-36, 2011. http://dx.doi.org/10.1590/S008062342011000500028 
JOHNSON, A.; COPNELL, B. Benefits and barriers for registered nurses undertaking post-graduate diplomas in paediatric nursing. Nurse Education Today, Oxford, v. 22, n. 2, p. 118-27, 2002.

https://doi.org/10.1054/nedt.2001.0672

LOPEZ, M. V. S.; GAZA, C. G.; RAMIREZ, J. J. H. A Comparative study of classroom and online distance modes of official vocational education and training. PLOS ONE, São Francisco, v. 9, n. 5, p. e96052, 2014. https://doi.org/10.1371/journal.pone.0096052

MENDONÇA, G. S.; CUNHA, C. M.; DIAS, E. P.; RESENDE, T. C.; MENDES-RODRIGUES, C. Attendance indicators for students in long term nursing courses at a university hospital. Bioscience Journal, Uberlândia, v. 32, n. 3, p. 753-763, 2016. http://dx.doi.org/10.14393/BJ-v32n3a2016-30114 https://doi.org/10.14393/BJ-v32n3a2016-30114

NEVES, E.; MAURO, M. Nursing in Brazil: trajectory, conquests and challenges. The Online Journal of Issues in Nursing, Silver Spring, v. 6, n. 1, 2000.

NI, C.; HUA, Y.; SHAO, P.; WALLEN, G. R.; XU, S.; LI, L. Continuing education among Chinese nurses: A general hospital-based study. Nurse Education Today, Oxford, v. 34, n. 4, p. 592-7, 2014.

https://doi.org/10.1016/j.nedt.2013.07.013.

PEREIRA, E. B. S.; JORGE, M. T.; OLIVEIRA, E. J.; JUNIOR, A. AL.; SANTOS, L. R.; MENDESRODRIGUES, C. Evaluation of the Multimodal Strategy for Improvement of Hand Hygiene as Proposed by the World Health Organization. Journal of Nursing Care Quality, Philadelphia, v. 00, n. 00, pp. 1-9, 2017. http://dx.doi.org/10.1097/NCQ.0000000000000197

PEREIRA E. B. S.; SOUZA R. C.; MENDES-RODRIGUES C.; SOUSA NETO R. L; BATISTA E. S.; RODRIGUES V. S.; LIMA JÚNIOR, A. J.; SILVA, D. V. Low increment in the knowledge concerning patient safety in a Nursing continuing education program. IOSR Journal of Nursing and Health Science, v. 6, n. 1, p. 55-61. 2017.

PERES, H. H. C.; LEITE, M. M. J.; GONÇALVES, V. L. M. Educação continuada: recrutamento e seleção, treinamento e desenvolvimento e avaliação de desempenho profissional. In: Kurcgant P, (Coord).

Gerenciamento de enfermagem. 2 ed. Rio de Janeiro: Guanabara Koogan; 2010.

PUETZ, B. E. Differences between Indiana registered nurse attenders and non attenders in continuing education in nursing activities. Journal of Continuing Education Nursing, Thorofare, v. 11, n. 2, p. 19-26, 1980. https://doi.org/10.3928/0022-0124-19800301-06

ROSS, K.; BARR, J.; STEVENS, J. Mandatory continuing professional development requirements: what does this mean for Australian nurses. BMC Nursing, London, v. 12, n. 9, p. 1-7, 2013. https://doi.org/10.1186/14726955-12-9.

SENGE, P. M. The Fifth Discipline. The heart and practice of learning organization. Doubleday, New York. 1990.

ŞENYUVA, E. Nurses Continuing education with the approach of distance education. International Journal of Social Sciences \& Interdisciplinary Research, Karachi, v. 1, n. 12, p. 47-56, 2012.

SOUZA NETO, R. L.; MENDES-RODRIGUES, C. Continuing Education Program: a comparative study between voluntary and mandatory regimes applied to a patient safety course. Journal of Patient Safety and Infection Control, New Delhi, v. 5, n. 1, p. 45-46, 2017. http://dx.doi.org/10.4103/jpsic.jpsic_10_17 